\section{地震性崩壤の一例}

\section{市瀬 由 自}

地殼運動の激しいかが国では，地震を直接的 契機としてしばしば大きな崩買が発生してい る。本短報ではかかる地震性崩壊の一例とし て, 跡津川断層帯上に発生して大きな被害を与 えた歸雲崩壊地について述べる（5万分の地形図 白川村図幅参照)。

歸雲崩壊は次のような特致を備えている。

（1）崩壊は猿ヶ馬場山の西方に続く平坦面 から急な山腹斜面汇遷移する附近より発生して いる。（2）濃留流紋岩扰よびその砕屑岩類を樑 くえぐって発生した崩壊であって, 崩壊土砂量 は $9 \times 10^{6} \mathrm{~m}^{3}$ (面積 $30 \mathrm{ha}$, 平均の深さ $30 \mathrm{~m}$ ) と推定 される。崩壊によって生じた滑落崖下部の馬蹄 型状凹地の一部は, その後の崖錐堆積物に占っ てお拉われているが, 滑落地塊は地之り運動に みられるような backward rotation を行なっ た痕跡を留めている。(3)この崩壊に関する災 害史（水利科学研究所 1968）をみると, 天正 13 年 (1586) に大地震があり, 飛州白川郷歸雲 城は城後の高山崩壊して城市を埋没し, 城主内 ケ島氏理以下一族家臣城下民衆のことごとく死 す」と記されている。なお，この記録に関連し て崩壊地周辺の地形をみると, 滑落地塊に続く 押出し崖錐状推積物（侵食の復活により段丘化 している）があり，庄川河床の左岸谷壁斜面の 一部にもこの時の押出し堆積物之推定されるも のが残っていることなどより, 歸雲崩壊地の下 方斜面では天正大地震に伴なら崩壊によって庄 川本流が堰止められ，一時ではあるが天然ダム を形成したものと考劣られる (写真)。(4)この 崩壊は跡津川断層帯上にあることや運動の性質 からみて地之り性崩壊の特徵を示している。
そして, 跡津川断渞帯上では安政 5 年 (1858) の地震時にも跡津川流域や宮川本流沿いに激震 地域が現われており (市川 1933), 跡津川断層帯 では地 形（河岸段丘の㚆位, offset stream, shutterridg，小断層崖の存在や水潅測量や水準測量の改贁結 果 松田 1966）などよりみて断層帯に沿う運動 が第四紀後期に至るまで継続している。

これらの諸特徴を併せ考えると, 歸雲崩壊は 現在も活動しつつある断層帯上に発生した地震 性崩壊であると言える。断層帯上に発生する地 震性崩壊つ上には，地之り性崩壊てみられる運 動を示して急激に崩れたり，河床を一時堰止め て天然ダムを形成さるなど, 避難の余地の殆ん どない破壊的なものがみられるだけに防災上留 意すべきであろう。

(1971.8.20 受理)

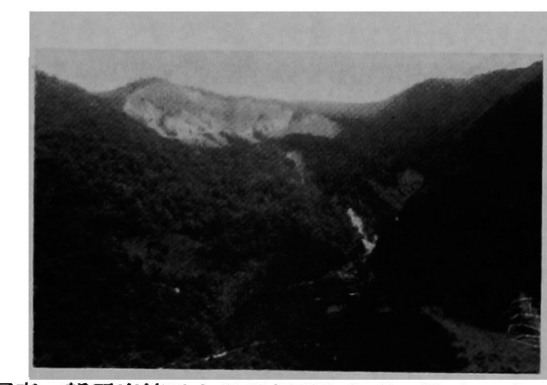

写真 歸雲崩壊地とその押出した砂（写真の右側に みられる崖錐状段丘堆積物が天正大地震時の ちのと推定される)

\section{文献}

市川 渡 (1933)：神通川およびその支流高平川流 域の地形 地理学評論 $9 \quad 150 \sim 161$

松田時彦 (1966)：跡津川断層の橫ずれ変位 地震 研究所巢報 $44 \quad 1190 \sim 1212$

水利科学研究所 (1968)：庄川上流地域の治山 調 査 報告書 $7 \quad 15 \sim 16$

\title{
An Example of the Seismic Landslide
}

\section{Yoshimi ICHINOSE}

As a case of the seismic landslide, Kaerigumo collapse occurred in the Atotsu-gawa shattered zone due to the Tenshō great earthquake (1586). The debris formed by the landslide dammed up the main course of the $R$. Shō, taking shape of a natural dam for a time. Owing to the extraordinary geographical phenomenon, villages were buried under debris and a number of people fell dead. The quantity of the debris produced by the landslide is estimated at about $9 \times 10^{6} \mathrm{~m}^{3}$. 